\title{
Geenitekniikalla kilpailukykyä maataloustuotantoon?
}

\author{
Jyrki Niemi \\ MTT Taloustutkimus (MTTL), Luutnantintie 13,00410 Helsinki, jyrki.niemi@mtt.fi
}

\section{Johdanto}

Geenitekniikka on meitä kaikkia viime aikoina hyvin paljon puhutellut aihe. Siitä on tullut osa kansalaisen arkipäivää, tosin enimmäkseen vasta mielikuvien tasolla. Siihen ei suhtauduta pelkästään uutena teknisenä menetelmänä, vaan siitä on tullut keskeinen modernin yhteiskunnan symboli, niin hyvässä kuin pahassa (Burkhardt 2002). Niinikään kannanotot uuden tekniikan hyödyistä ja haitoista vaihtelevat laidasta laitaan (Fischhoff \& Fischhoff 2001).

Geenitekniikan puolestapuhujat uskovat, että geenejä siirtelemällä voidaan tuottaa tulevaisuudessa enemmän, ravitsevampaa ja paremmin säilyvää ruokaa. Geenitekniikasta odotetaan myös ratkaisua aliravitsemus- ja nälkäongelmiin köyhissä maissa (Bourlaug 200). Geenitekniikkaan kriittisesti suhtautuvat korostavat puolestaan sitä, ettei muunneltujen geenien pitkäaikaisisista ympäristö- ja terveysvaikutuksista ole vielä tarpeeksi tietoa (Smyth ym. 2002, Snow 2002). Monet pitävätkin bioteknistä kehitystä hieman pelottavana - eräänlaisena kauhukuvana "uudesta uljaasta maailmasta."

Suomalaisessa maa- ja elintarviketaloudessa geenitekniikan käyttö ja taloudellinen merkitys ovat toistaiseksi vähäisiä. Testipelloille on ehtinyt kymmenkunta geenimuunneltua (gm) kasvia, esimerkiksi rapsi, peruna ja sokerijuurikas, mutta kaupallisessa tuotannossa niitä ei ole. Elintarviketeollisuus puolestaan käyttää geenitekniikkaa apuna jalostusprosesseissa. Gm-ainesosaa sisältäviä elintarvikkeita se ei kuitenkaan tarjoa.

Paineet geenitekniikan hyödyntämiseen kuitenkin kasvavat vuosi vuodelta. Käyttämättä jättämisen uskotaan pitkällä tähtäyksellä heikentävän Suomen maa- ja elintarviketalouden kilpailukykyä, jos siirtogeenisten lajikkeiden viljely muualla samanaikaisesti lisääntyy (Virolainen \& Niemi 2000).

Tässä artikkelissa analysoidaan geenitekniikan sovellutusten, erityisesti siirtogeenisten kasvien käytön, taloudellisia vaikutuksia elintarvikkeiden tarjontaketjulle Suomessa. Esille nousee kysymyksiä erityisesti siitä, mikä vaikutus siirtogeenisten kasvien viljelyllä on suomalaisen maatalouden tuottavuuteen ja kansainväliseen kilpailukykyyn, sekä miten mahdolliset hyödyt/haitat jakautuvat elintarvikeketjun eri osissa.

Tutkimus pohjautuu kansainväliseen ja kansalliseen kirjallisuusaineistoon. Koska Suomen maatalouden osalta geenitekniikan soveltamiseen liittyvää kirjallista materiaalia on vähän, tiedonhankintamenetelmänä on käytetty myös asiantuntijahaastatteluja. Suomen kannalta geenitekniikan käyttöön liittyykin tiettyjä erityiskysymyksiä, joita kirjallisuudessa ei ole paljon käsitelty. Erityisesti pohjoinen sijaintimme ja ilmastomme asettavat rajoituksia geenitekniikan käytölle (Niemi \& Virolainen 2002).

\section{Geenitekniikka kasvinjalostuksessa}

Geenitekniikan ero perinteiseen kasvinjalostukseen on siinä, että sen avulla voidaan saattaa yhteen geenejä sellaisista eliöistä, joiden välillä se luonnossa olisi mahdotonta. Näin kasviin saatetaan lisätä vaikkapa kalan geeni. Samalla kasvinjalostusta voidaan tehostaa ja siihen käytettävää aikaa lyhentää jopa vuosilla.

Geenisiirroilla voidaan parantaa viljelykasvien satoisuutta ja laatua kehittämällä lajikkeita, jotka ovat vastustuskykyisiä erilaisille kasvitaudeille ja tuhohyönteisille. Vaihtoehtoisesti viljelykasveja voidaan tehdä torjunta-aineita sietäviksi, jolloin viljelykasville lähisukuiset rikkakasvit voidaan torjua tehokkaammin. Esimerkiksi siirtämällä erään bakteerin geeni soijaan siitä on kehitetty rikkakasvihävitettä kestävä lajike.

Muita tavoitteita geeniteknisessä kasvinjalostuksessa ovat mm. kypsymiseen vaikuttavien tekijöiden muuttaminen, ravintoarvon kasvattaminen tai vaikeiden ympäristöolosuhteiden kestäminen. Geenitekniikalla voidaan parantaa vaikkapa viljelykasvien kestävyyttä kuivuutta vastaan ja vähentää siten kasteluveden tarvetta. 


\section{Geeniteknisten menetelmien käyttö maataloustuotannossa}

Maatalouden tuottavuuden kehityksessä teknologinen kehitys on ollut perinteisesti tärkein yksittäinen tekijä. Tuotantofunktion muutoksena teknologinen kehitys vaikuttaa tuotantopanosten kysyntään ja se tehostaa myös investointeja. Lyhyesti sanottuna maatalouden kokonaistuottavuus paranee uuden teknologian käyttöönoton myötä. Myös geeniteknologian avulla voidaan kehittää maatalouden tuottavuutta.

Geenitekniikan aiheuttama teknologinen muutos on kuitenkin erilainen kuin se mihin maataloudessa aikaisemmin on totuttu, koska geenitekniikan eri aalloilla on erilainen vaikutus markkinarakenteeseen, markkinahintoihin ja hyötyjen jakaantumiseen elintarvikeketjussa (Lence \& Hayes 2003). Geenitekniikka ei ole siten merkittävä muutos vain teknologiana, vaan myös sen aiheuttaman tarjontaketjun muutoksen vuoksi. Koska geeniteknologia on korkean teknologian ala, erityisesti patentit ja tekijänoikeudet nousevat tärkeään rooliin. Patenttien laaja käyttö puolestaan johtaa uudenlaisiin ongelmiin elintarvikeketjun eri osissa.

Geenitekniikan käyttöönotto maataloudessa voidaan jakaa vaikutusten perusteella karkeasti kahteen osaan. Ensiksikin on olemassa kustannuksia alentavaa geeniteknologiaa (cost-reducing technological change), joka alentaa tuotannon yksikkökustannuksia joko lisäämällä satoja tai vähentämällä käytettyä panosmäärää. Toiseksi on olemassa laatua parantavaa geeniteknologiaa (quality-enhancing technological change), joka parantaa ruuan laatua kuten makua, rakennetta, säilyvyyttä, ravintoarvoa tms. Näillä erilaisilla teknologian muutoksilla on myös erilainen vaikutus markkinarakenteeseen, markkinahintoihin ja hyötyjen jakaantumiseen elintarvikeketjussa. Ns. ensimmäisen aallon tuotteet ovat nimenomaan kustannuksia alentavia ja toisen ja kolmannen aallon tuotteet laatua parantavia.

Toistaiseksi geenitekniikan käyttöönotto on koskenut ensimmäisen aallon tuotteita. Ensimmäisen aallon tekniikan hyödyt maanviljelijöille voidaan tiivistää seuraavasti (Ismael ym. 2002, Kalaintzandonakes 1999, Klotz-Ingram ym. 1999):

- tuhoeläinten torjunnan kustannusten aleneminen,

- kasvaneet sadot,

- parantunut riskinhallintakyky,

- vakuus tuhoeläimiä vastaan,

- ajan säästö,

- säästöt laitekustannuksissa (eivät liity maan muokkaukseen tms.),

- maan käytön tehostuminen kasvien parantuneen tilankäytön ansiosta.

Yhdysvalloissa saatujen kokemusten valossa siirtogeenisten kasvien viljely on johtanut merkittäviin sadon lisäyksiin sekä monissa tapauksissa myös torjunta-aineiden käytön vähenemiseen ja sitä kautta tuotannon yksikkökustannusten alentumiseen (Marra ym. 2003). Keskimääräinen sadon nousu siirtogeenisillä kasveilla (maissi, puuvilla ja soija) on ollut noin 5-20\%, mitä voidaan pitää merkittävänä sadonlisäyksenä.

Siirtogeenisen kasvin parempi satoisuus on ollut yhteydessä lähinnä kasvinsuojeluaine- ja tuhoeläinkestävyyteen. Geenitekniikan avulla voidaan kuitenkin parantaa myös kasvin kuivuuden, suolaisuuden ja tulvien sietokykyä, mikä vaikuttaa suoraan satoisuuteen. Esimerkiksi Suomessa kylmänsietokestävyys lisäisi luonnollisesti myös satoisuutta, ja siten meillä voitaisiin viljellä uusia eteläisempiä ja satoisampia lajikkeita (Salo ym. 1998).

On kuitenkin pidettävä mielessä, että tähän mennessä saatujen kokemusten pohjalta tehtäviä yleistyksiä vaikeuttaa se, että pitkällä aikavälillä tuottavuuden lisäykset riippuvat siirtogeenisten lajikkeiden hyötyominaisuuksien pysyvyydestä, jota esimerkiksi geenien leviäminen rikkaruohoihin tai resistenttien hyönteisten kehittyminen voivat uhata (Kloppenburg \& Burrows 1996, Snow 2002).

Valtaosa maailman siirtogeenisten kasvien viljelystä tapahtuu Yhdysvalloissa, jossa gmtuotteille ei vaadita pakkausmerkintöjä, eikä eri raaka-aine-eriä ole pidettävä erillään. Geenitekniikkaa hyödynnetäänkin tällä hetkellä eniten Yhdysvalloissa, mutta sen käyttö yleistyy myös muualla Euroopan ulkopuolella - etenkin Argentiinassa, Kanadassa ja Kiinassa. Lajiketasolla nopeimmin lisääntyvät siirtogeenisen soijan, maissin ja kevätrapsin viljely. Esimerkkinä voidaan mainita, että jo puolella maailman soijapelloista kasvatetaan geenimanipuloitua soijaa. Suuntaa-antavien arvioiden mukaan viljelypinta-alat kasvavat siten, että vuonna 2004 siirtogeenisten lajikkeiden kokonaispinta-alan arvioidaan kasvavan noin 60 milj. hehtaariin vuoden 199826 milj. hehtaarista. Myös tarjolla olevien lajikkeiden lukumäärä kasvaa. 
Euroopassa siirtogeenisten lajikkeiden viljely on edelleen erittäin vähäistä. Euroopan osuus gmkasvien kokonaispinta-alasta on alle prosentin. Monet pitävät tätä riskinä eurooppalaisen maatalouden kilpailukyvylle maailmanmarkkinoilla. EU on jarruttanut geenimuunneltujen tuotteiden viljelyä ja tuontia, vaikka kenttäkokeita tehdään monessa jäsenmaassa - erityisesti Ranskassa, Italiassa ja Britanniassa. Suomessakin peltokokeisiin on ehtinyt kymmenkunta geneettisesti muunneltua kasvia. Tuotannollisessa viljelyssä niitä ei vielä ole.

Gm-elintarvikkeiden pääsy EU-markkinoille on kuitenkin helpottumassa jo tänä vuonna, kun sekä EU:n maatalous- että ympäristöministerit hyväksyivät vuoden 2003 aikana 2002 gm-tuotteiden jäljitettävyyttä ja merkintöjä koskevan asetuksen. Jäsenmaat sopivat, että tuotteessa on oltava merkintä geenimuuntelusta, jos se sisältää yli 0,9 prosenttia gm-organismeja. Suomessakin on siten syytä varautua gm-elintarvikkeiden tuloon.

\section{Vaikutukset maatalouden kannattavuuteen ja kilpailukykyyn}

Gm-viljelyn lisääntyminen maailmalla osoittaa, että se on ollut viljelijälle edullinen vaihtoehto - ainakin toistaiseksi (Marra ym. 2003). On kuitenkin syytä suhtautua varauksella lupauksiin, joiden mukaan geenitekniikan avulla pystyttäisiin nostamaan suomalaisen maatalouden kansainvälistä kilpailukykyä. Ajan mittaan ero muuhun maailmaan saattaa jopa kasvaa. Vaikka geenitekniikan avulla pystyttäisiinkin nostamaan satoja tai alentamaan tuotantopanoksia vaikkapa kymmenellä prosentilla, se sama kymmenen prosentin lisäys esimerkiksi Keski-Euroopassa on tonneissa mitattuna suurempi kuin meillä Suomessa (Niemi \& Virolainen 2002).

Geenitekniikasta hyötyvät eniten ne viljelijät, jotka ottavat uuden tekniikan ensimmäisenä käyttöön. Pitkällä aikavälillä uuden tekniikan mukanaan tuomat edut valuvat todennäköisesti viljelijöiltä elintarvikeketjun muihin portaisiin.

Geenitekniikan omaksuminen suomalaisilla maatiloilla ei Virolaisen (2001) mukaan muodostuisi ongelmaksi. Vaikka tilojen keskikoko on kansainvälisesti katsoen pieni, ovat pienetkin suomalaistilat hyvin mukana tietovirrassa ja saavat tarvitsemansa uuden tiedon helposti. Geenitekniikka ei siten vaadi tiloilta kohtuuttomia panostuksia. Investoinnit rajoittuvat lähinnä uusiin siemeniin ja torjuntaaineisiin.

Itse geenisiirtojen vaatimat suuret tutkimuspanostukset ja Suomen erityiset viljelyolosuhteet huomioon ottaen on kuitenkin todennäköistä, etteivät suuret monikansalliset yritykset lähde kehittämään Suomen pohjoiseen ilmastoon ja pienille markkinoille suunnattuja lajikkeita. Suomessa viljeltävät lajikkeet on jalostettava joko kotimaisen tutkimus- ja kehitystyön tuloksina tai hankkimalla ulkomaisilta yrityksiltä geenejä ja gm-kasveja kotimaisen kasvinjalostuksen käyttöön. Suomalaisia tuottajien huolenaiheena on se, että he joutuisivat mahdollisesti ostamaan muita kalliimmalla uudet vastustuskykyiset vilja- ja eläinlajikkeet.

Geenitekniikan nopeuttaessa torjunta-aine- ja siemenkaupan keskittymistä entistä harvempiin ja suurempiin yrityksiin, viljelijän neuvotteluvoiman suhteessa panosten myyjään ja tuotteen ostajaan pelätään markkinoilla heikentyvän. Viljelijä saa gm-siemeniä vain tekemällä sopimuksen. Lisäksi, jos ja kun gm- ja muut tuotteet halutaan pitää erillään, se onnistuu vain entistä tarkemmin viljelysopimuksin - ja silloin sellainen pitää tehdä kummassakin tapauksessa, oli viljelyssä gm-lajike tai ei.

Gm-tuotteiden pitäminen erillään tavanomaisista tuotteista aiheuttaa myös lisäkustannuksia. Suomessa pienet tuotantomäärät ja pitkät matkat lisäävät keruun ja lajittelun kustannuksia. Molempien tuoteketjujen ylläpito saattaakin käydä niin kalliiksi, että toinen vaihtoehto häviää markkinoilta (Virolainen 2001, Niemi ym. 2003).

Gm-lajikkeiden viljelyn lisääntyessä muualla, niihin liittyvä tuottavuuden parantaminen heikentää suomalaisen maatalouden kilpailukykyä. Tätä taustaa vasten on tuottajien edun mukaista, että saatavilla on Suomen olosuhteissa menestyviä gm-lajikkeita.

\section{Kuluttajien asenteet ja muuntogeenisen ruuan kysyntä}

Keskeistä geenimuunneltujen (gm) elintarvikkeiden tulevaisuudelle Suomessa ja koko Euroopassa on kuitenkin se, miten kuluttajat niihin suhtautuvat. Vielä ei voi tietää kuinka käy, koska merkittyjä gmtuotteita ei ole markkinoilla. Tutkimusten mukaan gm-elintarvikkeiden käyttöönotto epäilyttää kuluttajia, koska uuden tekniikan vaikutuksista ei ole aiempaa kokemusta. Kuluttajat kaipaavat lisää tietoa mm. geeniteknisten tuotteiden vaikutuksista maataloustuotantoon, tuotteiden turvallisuuteen, tuotan- 
non ja viljelyn haitattomuuteen ympäristölle sekä valvonnan luotettavuudesta. Kuluttajien varauksellinen suhtautuminen Euroopassa vaikeuttaa siirtogeenisen kasviraaka-aineen menekin ja hinnan ennakointia (European Commission 2000, Gaskell 2000).

Koska elintarvikkeiden kysyntä riippuu paljon kuluttajien joskus nopeastikin vaihtuvista reaktioista, elintarvikkeita valmistavat yritykset ovat puolestaan verraten haluttomia ottamaan riskejä tuodessaan uusia tuotteita markkinoille. Näin myös muuntogeenisten elintarvikkeiden kohdalla, joihin monien kuluttajien tiedetään suhtautuvan varauksellisesti. Etenkään pienet ja keskisuuret yritykset eivät ole aktiivisesti kehittämässä siirtogeenisistä kasveista valmistettuja elintarvikkeita.

Jos kuluttajat kuitenkin hyväksyvät gm-elintarvikkeet, on selvää, että maatalous ja elintarviketeollisuus tulevat niitä tarjoamaan. Muuntogeenisten kasvien parempi tuottavuus saattaa aikanaan alentaa eräiden elintarviketeollisuuden käyttämien raaka-aineiden hintoja. Parantuneen tuottavuuden vaikutukset elintarvikkeiden hintoihin jäävät kuitenkin todennäköisesti varsin pieniksi, koska useimmissa elintarvikkeissa raaka-aineen osuus kuluttajahinnasta on vähäinen.

\section{Kirjallisuus}

Bourlaug, N. 2000. Ending world hunger: the promise of biotechnology and the threat of antiscience zealotry. Plant physiology 124, s. 487-490.

Burkhardt, J. 2002. Biotechnology's future benefits: prediction or promise? AgBioForum, 5, s. 20-24. Saatavilla http://www.agbioforum.org.

European Commission 2000. Eurobarometer 2000 summary report. Saatavilla http://europa.eu.int/comm/ research/press/2000/pr2704en-ann2.html.

Fischhoff, B. \& Fischhoff, I. 2001. Publics' opinions about biotechnologies. AgBioForum, 4, s. 155-162. Saatavilla http://www.agbioforum.org.

Gaskell, G. 2000. Agricultural biotechnology and public attitudes in the European Union. AgBioForum, 3, s. 8796. Saatavilla http://www.agbioforum.org.

Ismael, Y., Bennett, R., \& Morse, S. 2002. Benefits from Bt cotton use by smallholder farmers in South Africa. AgBioForum, 5, s. 1-5. Saatavilla http://www.agbioforum.org.

Kalaitzandonakes, N. 1999. A farm level perspective on agrobiotechnology: how much value and for whom? AgBioForum 2, s. 61-64. Saatavilla http: //www.agribioforum.org.

Kloppenburg, J. Jr. \& Burrows, B. 1996. Biotechnology to the rescue? Twelve reasons why biotechnology is incompatible with sustainable agriculture. The Ecologist 26, s. 61-67.

Klotz-Ingram, C., Jans, S., Fernandez-Cornejo, J., \& McBride, W. 1999. Farm-Level production effects related to the adoption of genetically modified cotton for pest management. AgBioForum 2, s. 73-84. Saatavilla http://www.agbioforum.org.

Lence, S., and Hayes, D. 2003. Impact of biotech grains on market structure and societal welfare. AgBioForum, 5, s. 85-89. Saatavilla http://www.agbioforum.org.

Marra, M., Pardey, P. \& Alston, J. 2003. The payoffs to transgenic field crops: an assessment of the evidence. AgBioForum 6, s. 43-50. Saatavilla http://www.agbioforum.org.

Niemi, J., Mäkelä, S. \& Tuomisto, J. 2003. The distribution of costs and benefits from the commercial introduction of genetically modified crops: a case study on potato in Finland. A paper presented at the 7th International Conference on Agricultural Biotechnology Research (ICABR), Ravello (Italy), 29.6-3.7. 2003. 15 s. Saatavilla http://www.economia.uniroma2.it/conferenze/icabr2003/papers/index.htm.

Niemi, J. \& Virolainen, M. 2002. Ex-ante economic assessment of adopting genetically engineered crops in Finland. In: V. Santaniello, R.E. Evenson and D. Zilberman (toim.) 2002. Market Development for Genetically Modified Food. CAB International, s. 159-166.

Salo, A., Kauppinen, V. \& Rask, M. 1998. Loppuraportti kasvitekniikasta: Kasvigeenitekniikka ravinnontuotannossa. Tulevaisuusvaliokunnan teknologiajaosto. Eduskunnan kanslian julkaisu 1998/4. $199 \mathrm{~s}$.

Smyth, S., Khachatourians, G. \& Phillips, P. 2002. Liabilities and economics of transgenic crops. Nature Biotechnology 20, s. 537-541.

Snow, A. 2002. Transgenic crops - why gene flow matters. Nature Biotechnology 20, s.542.

Virolainen, M. \& Niemi, J. 2000. Geenitekniikan ja muuntogeenisen ruuan taloudelliset vaikutukset Suomen elintarviketjussa. Maatalouden taloudellisen tutkimuslaitoksen selvityksiä 7/2000. $52 \mathrm{~s}$.

Virolainen, M. 2001. Geenitekniikan omaksumisen taloudelliset vaikutukset Suomen elintarvikeketjussa: Casetutkimukset rypsistä ja perunasta. MTT Taloustutkimuksen selvityksiä 19/2001. $49 \mathrm{~s}$. 